\title{
COVID-19: EPIDEMIOLOGY, PATHOGENICITY AND GLOBAL UPDATES
}

\section{MANJINDER SINGH ${ }^{1}$, MANJU NAGPAL ${ }^{1}$, VARINDER SINGH ${ }^{1}$, AMEYA SHARMA1,2, GITIKA ARORA DHINGRA ${ }^{3}$, PARAMJOT MAMAN ${ }^{4}$, VIVEK PURI ${ }^{12^{*}}$}

1Chitkara College of Pharmacy, Chitkara University, Punjab, India, ${ }^{2}$ Chitkara University School of Pharmacy, Chitkara University, Himachal Pradesh, India, ${ }^{3}$ NCRD's Sterling Institute of Pharmacy, Nerul, Navi Mumbai, India, ${ }^{4}$ Paraxel International Ltd, Mohali, Punjab, India Email: vivek.puri@chitkara.edu.in

Received: 25 May 2020, Revised and Accepted: 03 Jul 2020

\section{ABSTRACT}

Novel coronavirus (COVID-19) is a highly contagious virus that originated from China and has become a major threat in the current time. Presently, finding an effective treatment strategy for COVID-19 is in infancy. Worldwide, numerous clinical trials employing different treatment strategies (antiviral drugs and vaccines) are in progress to develop an effective therapeutic regimen against COVID-19. Literature related to the epidemiology, mortality, pathogenicity, treatment strategies and clinical data was studied and database was collected using various search engines such as j-gate, google scholar, scihub, pubmed, sciencedirect etc. The present review systematically summarises the published information about epidemiology, various stages of pandemic, mortality, pathogenicity, modes of transmission, clinical characteristics, methods of prevention, ongoing treatment strategies and drugs under clinical trials associated with COVID-19 with a hope to avoid possible threatening of the lives of millions of human beings and provide directions for future studies.

Keywords: COVID-19, Coronavirus, Epidemiology, Pathology, Zoonotic, Prevention and Treatment

(C) 2020 The Authors. Published by Innovare Academic Sciences Pvt Ltd. This is an open access article under the CC BY license (http://creativecommons.org/licenses/by/4.0/) DOI: http://dx.doi.org/10.22159/ijap.2020v12i5.38439. Journal homepage: https://innovareacademics.in/journals/index.php/ijap

Speedy peer review was done as the subject of the manuscript was related with pandemic.

\section{INTRODUCTION}

Over the past two decades, coronaviruses (CoVs) have been associated with 99 significant disease outbreaks in East Asia and the
Middle East. The MERS (Middle East respiratory syndrome) and SARS (Severe acute respiratory syndrome) and began to emerge in 2002 and 2012. Fig. 1 deliberates the spread of various viral infections with its minimum and maximum rate $[1,2]$.

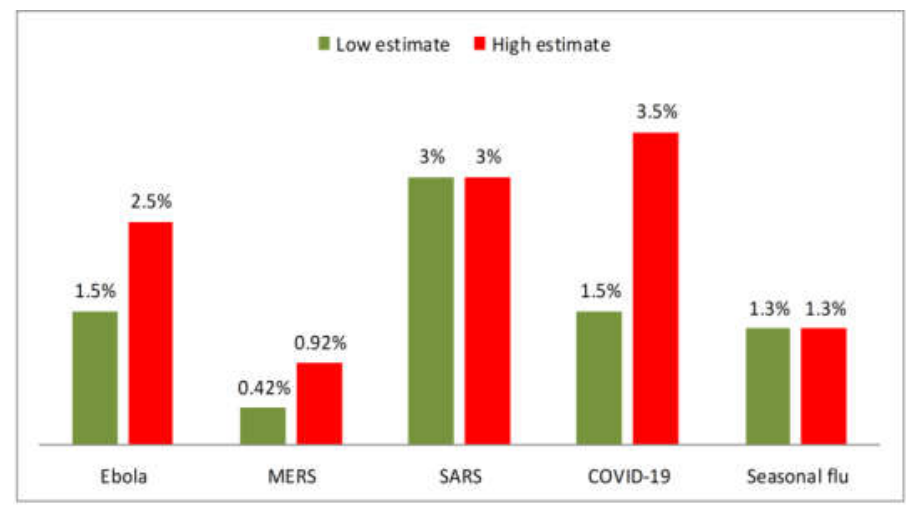

Fig. 1: Percentage range of various viral infections spread (self-made)

A novel CoV has become prominent in late 2019 and continued till today. It may impose health threat globally and has become influential in giving the evolved epidemic in China and other areas. Currently, health care professionals and workers are putting efforts worldwide to control the disease outbreaks caused by the novel $\mathrm{CoV}$ (originally named 2019-nCoV). It was first identified in Wuhan City, Hubei Province, China, on December 12th 2019 [2-4]. On February $11^{\text {th }} 2020$, the World Health Organization (WHO) announced the official designation for this current $\mathrm{CoV}$ associated disease to be "COVID-19". Corona means crown, the well-known virus acquired this name from a sharp (spiny) crown of glycoproteins on its surface $[5,6]$. The various mammals and birds were typically infected by this RNA virus. The primary cluster of patients were found to be connected with the Wuhan's huanan South China seafood market [7, 8]. CoVs belong to the family Coronaviridae (subfamily Coronavirinae), the members of which infect a broad range of hosts, producing symptoms and diseases ranging from a common cold to severe and ultimately fatal illnesses such as SARS, MERS, and as of present, COVID-19 breakthrough to respiratory diseases such as ARDS (acute respiratory distress syndrome), pneumonia and multiorgan failure. Countless people did not show any symptoms $[9,10]$. Till now, globally 55,00,679 total cases of COVID-19 were reported, out of which $28,51,888(52 \%)$ were found to be active, $3,46,721$ $(6 \%)$ patients were died and $23,02,070(42 \%)$ were recovered as depicted in fig. 2. Favourably, infants have been intermittently affected without any death loss. COVID-19 has represented a high negative impact on the economy of China as well as a few other nations. The lessons from such earlier threats of SARS, MERS and of the current COVID-19 situations need to be kept in mind for active strategy planning to counter such emerging and zoonotic pathogens that could pose pandemic threats while putting human lives at bay $[11,12]$. 


\section{Active Cases $⿴$ Recovered $\backsim$ Deaths}

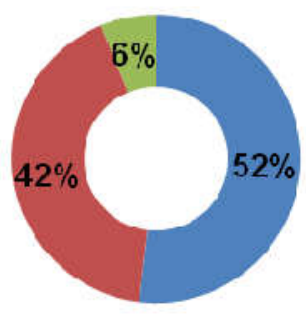

Fig. 2: COVID-19 cases, recoveries, deaths worldwide as of May 24, 2020 (self-made)

The SARS-CoV-2 is an envelope, spherical shape, single-stranded plus sense RNA (Ribonucleic acid) virus with helical symmetry belonging to beta coronaviruses of Coronaviridae. The virus has peplomers made up of glycoprotein projected over the envelope in a manner of crown (hence named corona), and these spike proteins help in binding with receptors present in the body of animals (bats, rodents, civets, cats, malayan pangolins, camels, among other potentially competent hosts) and humans. Modifications at the level of spikes on receptor binding ligands are responsible for zoonotic spillover and crossing of the species barrier. As per high genomic similarities, it is suggested that SARS-CoV-2 (Severe acute respiratory syndrome coronavirus-2) producing COVID-19 in humans has its origin from bats as it acted as natural ancestral host. Fig. 3 shows various strains of coronaviruses affecting human population till date [13-16]

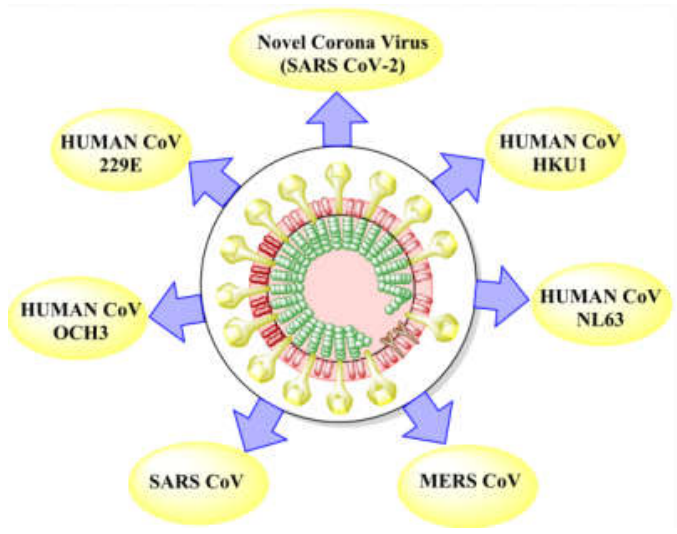

Fig. 3: Various strains of corona virus (self-made)

\section{Epidemiology}

The novel coronavirus (2019-nCov) has emerged in China, which posed an International Public Health Emergency in a couple of weeks, and very recently attained the position of a very high-risk category by World Health Organization (WHO). The virus, SARSCoV-2 was named by the ICTV (International Committee on Taxonomy of Viruses), and the disease was mentioned as COVID-19 (Coronavirus Disease-19) [17, 18]. In December 2019, many pneumonia cases clustered in Wuhan city were reported and searches for the source have shown Huanan Seafood Market as the origin $[19,20]$. The first case of the COVID-19 epidemic was discovered with unexplained pneumonia on December 12, 2019, and 27 viral pneumonia cases with seven being severe, were officially announced on December 31, 2019 [21]. The 515 environment samples were collected from the patients related to businesses and their neighbours on January $1^{\text {st }}$ of 2020 and delivered immediately for testing to medical laboratory centers such as IVD (Institute of Viral Disease), CCDC (Chinese Center for Disease Control and Prevention). Furthermore, 70 more samples were collected on January $12^{\text {th }} 2020$ from the seafood market (wildlife shops) for evaluation. These tests indicated that out of 585 samples, 33 samples contained 2019-nCoV, suggesting that virus was initiated from animals vended in the market of seafood. On $22^{\text {nd }}$ January, 2020 , novel CoV has been declared to be originated from bats and belonged to group 2 of $\beta$-coronavirus that contains SARS-CoV. Though SARS-CoV and COVID-19 are of the same $\beta$-coronavirus subgroup family. Their similarity at genome level is $70 \%$, and the novel group has been found to show genetic differences from SARSCoV. This virus outbreak has been raised during the Spring Festival in China as SARS epidemic occurred. Traditionally, spring festival is the most famous festival in China and approximately 3 billion people travel country widely. These conditions begun favourable circumstances for the spread of this extremely contagious virus and severe difficulties in prevention and control of the epidemic $[22,23]$. This virus can infect all age individuals. As per Bin Cao, the Executive Vice President of the Institute of Respiratory Medicine, CAMS (Chinese Academy of Medical Sciences), around 72\% confirmed infectious patients are of more than $40 \mathrm{y}$ old among them $64 \%$ are only males. Around $40 \%$ of the patients also suffering from diabetes and high blood pressure.

Early detection, diagnose, quarantine and treatment are effective preventive measurements which inhibit human-to-human transmission and reduces secondary infections that develops amidst close contacts and health professionals [24, 25].

Besides affecting China (mainly), SARS-CoV-2 (COVID-19) has now spread in the whole world. Out of cumulative $28,51,888$ active cases, $3,46,721$ human deaths and 23,02,070 recovered have been documented as of May 24, 2020. Currently, the virus has been spread to more than 200 countries and territories with a number of confirmed cases. There are top 10 countries which are highly affected by stage-IV (epidemic) namely USA $(16,86,436)$, Brazil $(3,65,213)$, Russia $(3,44,481)$, Spain $(2,82,852)$, UK $(2,59,559)$, Italy $(2,29,858)$, France $(1,82,584)$, Germany $(1,80,328)$, Turkey $(1,56,827)$ and India $(1,38,917)$. Fig. 4 depicts the worldwide spread of novel coronavirus. In spite of various strategies issued by numerous health agencies to combat the transmission of COVID-19, the growing number of infected patients globally remains the matter of concern as shown in fig. 5 .

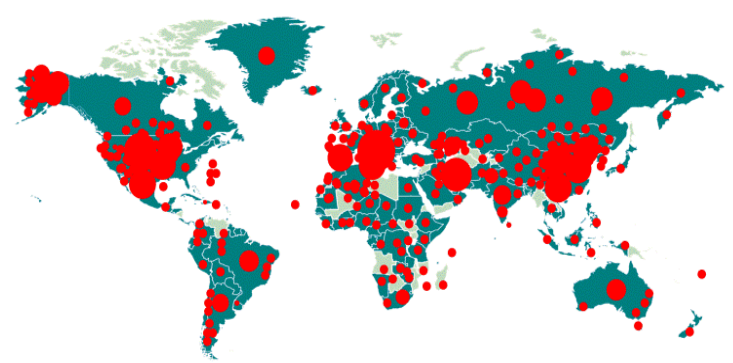

Fig. 4: Diagrammatic representation of worldwide novel corona virus spread (self-made)

\section{Stages of COVID-19}

There are four stages of COVID includes one who has travelled to foreign countries, which is already virus-hit and return to his/her origin country. In the second, the person has been in contact with the patient having travel history. After that, the transmission occurs when a patient was not exposed to corona infected person or the one who has no travel history to any virus hit country. The larger areas are affected when this transmission occurs. Last stage is the worst stage in which the disease grabs an epidemic shape with no endpoint. 
Table 1: Worldwide novel coronavirus spread, recoveries, deaths as of May 24, 2020

\begin{tabular}{|c|c|c|c|c|c|}
\hline Country & Active cases & Recovered & Deaths & Total cases & Reference \\
\hline Afghanistan & 9,289 & 1,075 & 218 & 10,582 & {$[11,12]$} \\
\hline Albania & 177 & 789 & 32 & 998 & {$[11,12]$} \\
\hline Algeria & 2,922 & 4,784 & 600 & 8,306 & {$[11,12]$} \\
\hline Andorra & 58 & 653 & 51 & 762 & {$[11,12]$} \\
\hline Angola & 47 & 18 & 4 & 69 & {$[11,12]$} \\
\hline Anguilla & 0 & 3 & & 3 & {$[11,12]$} \\
\hline Antigua and Barbuda & 3 & 19 & 3 & 25 & {$[11,12]$} \\
\hline Argentina & 7,892 & 3,732 & 452 & 12,076 & {$[11,12]$} \\
\hline Armenia & 3,516 & 3,064 & 81 & 6,661 & {$[11,12]$} \\
\hline Aruba & 3 & 95 & 3 & 101 & {$[11,12]$} \\
\hline Australia & 481 & 6,531 & 102 & 7,114 & {$[11,12]$} \\
\hline Austria & 800 & 15,063 & 640 & 16,503 & {$[11,12]$} \\
\hline Azerbaijan & 1,466 & 2,607 & 49 & 4,122 & {$[11,12]$} \\
\hline Bahamas & 43 & 46 & 11 & 100 & {$[11,12]$} \\
\hline Bahrain & 4,537 & 4,587 & 14 & 9,138 & {$[11,12]$} \\
\hline Bangladesh & 26,229 & 6,901 & 480 & 33,610 & {$[11,12]$} \\
\hline Barbados & 15 & 70 & 7 & 92 & {$[11,12]$} \\
\hline Belarus & 21,844 & 14,155 & 199 & 36,198 & {$[11,12]$} \\
\hline Belgium & 32,540 & 15,272 & 9,280 & 57,092 & {$[11,12]$} \\
\hline Belize & 0 & 16 & 2 & 18 & {$[11,12]$} \\
\hline Benin & 106 & 82 & 3 & 191 & {$[11,12]$} \\
\hline Bermuda & 43 & 81 & 9 & 133 & {$[11,12]$} \\
\hline Bhutan & 21 & 6 & & 27 & {$[11,12]$} \\
\hline Bolivia & 5,384 & 629 & 250 & 6,263 & {$[11,12]$} \\
\hline Bosnia and Herzegovina & 577 & 1,680 & 144 & 2,401 & {$[11,12]$} \\
\hline Botswana & 15 & 19 & 1 & 35 & {$[11,12]$} \\
\hline Brazil & $1,92,556$ & $1,49,911$ & 22,746 & $3,65,213$ & {$[11,12]$} \\
\hline British Virgin Islands & 1 & 6 & 1 & 8 & {$[11,12]$} \\
\hline Brunei & 3 & 137 & 1 & 141 & {$[11,12]$} \\
\hline Bulgaria & 1,457 & 840 & 130 & 2,427 & {$[11,12]$} \\
\hline Burkina Faso & 90 & 672 & 52 & 814 & {$[11,12]$} \\
\hline Burundi & 21 & 20 & 1 & 42 & {$[11,12]$} \\
\hline Cabo Verde & 222 & 155 & 3 & 380 & {$[11,12]$} \\
\hline Cambodia & 2 & 122 & & 124 & {$[11,12]$} \\
\hline Cameroon & 2,860 & 1,865 & 165 & 4,890 & {$[11,12]$} \\
\hline Canada & 34,290 & 43,985 & 6,424 & 84,699 & {$[11,12]$} \\
\hline CAR & 581 & 22 & 1 & 604 & {$[11,12]$} \\
\hline Caribbean Netherlands & 0 & 6 & & 6 & {$[11,12]$} \\
\hline Cayman Islands & 67 & 61 & 1 & 129 & {$[11,12]$} \\
\hline Chad & 400 & 215 & 60 & 675 & {$[11,12]$} \\
\hline Channel Islands & -4 & 517 & 45 & 558 & {$[11,12]$} \\
\hline Chile & 40,236 & 28,148 & 718 & 69,102 & {$[11,12]$} \\
\hline China & 83 & 78,268 & 4,634 & 82,985 & {$[11,12]$} \\
\hline Colombia & 15,432 & 5,016 & 727 & 21,175 & {$[11,12]$} \\
\hline Comoros & 65 & 21 & 1 & 87 & {$[11,12]$} \\
\hline Congo & 324 & 147 & 16 & 487 & {$[11,12]$} \\
\hline Costa Rica & 300 & 620 & 10 & 930 & {$[11,12]$} \\
\hline Croatia & 118 & 2,027 & 99 & 2,244 & {$[11,12]$} \\
\hline Cuba & 170 & 1,689 & 82 & 1,941 & {$[11,12]$} \\
\hline Curaçao & 2 & 14 & 1 & 17 & {$[11,12]$} \\
\hline Cyprus & 324 & 594 & 17 & 935 & {$[11,12]$} \\
\hline Czechia & 2,562 & 6,078 & 315 & 8,955 & {$[11,12]$} \\
\hline Denmark & 898 & 9,900 & 562 & 11,360 & {$[11,12]$} \\
\hline Diamond Princess & 48 & 651 & 13 & 712 & {$[11,12]$} \\
\hline Djibouti & 1,196 & 1,064 & 10 & 2,270 & {$[11,12]$} \\
\hline Dominica & 0 & 16 & & 16 & {$[11,12]$} \\
\hline Dominican Republic & 6,210 & 8,133 & 458 & 14,801 & {$[11,12]$} \\
\hline DRC & 1,761 & 317 & 63 & 2,141 & {$[11,12]$} \\
\hline Ecuador & 30,088 & 3,560 & 3,108 & 36,756 & {$[11,12]$} \\
\hline Egypt & 11,694 & 4,807 & 764 & 17,265 & {$[11,12]$} \\
\hline El Salvador & 1,247 & 633 & 35 & 1,915 & {$[11,12]$} \\
\hline Equatorial Guinea & 784 & 165 & 11 & 960 & {$[11,12]$} \\
\hline Eritrea & 0 & 39 & & 39 & {$[11,12]$} \\
\hline Estonia & 227 & 1,532 & 64 & 1,823 & {$[11,12]$} \\
\hline Eswatini & 92 & 156 & 2 & 250 & {$[11,12]$} \\
\hline Ethiopia & 425 & 152 & 5 & 582 & {$[11,12]$} \\
\hline Faeroe Islands & 0 & 187 & & 187 & {$[11,12]$} \\
\hline Falkland Islands & 0 & 13 & & 13 & {$[11,12]$} \\
\hline Fiji & 3 & 15 & & 18 & {$[11,12]$} \\
\hline Finland & 1,472 & 4,800 & 307 & 6,579 & {$[11,12]$} \\
\hline France & 89,600 & 64,617 & 28,367 & $1,82,584$ & {$[11,12]$} \\
\hline
\end{tabular}




\begin{tabular}{|c|c|c|c|c|c|}
\hline French Guiana & 182 & 145 & 1 & 328 & {$[11,12]$} \\
\hline French Polynesia & 0 & 60 & & 60 & {$[11,12]$} \\
\hline Gabon & 1,463 & 459 & 12 & 1,934 & {$[11,12]$} \\
\hline Gambia & 11 & 13 & 1 & 25 & {$[11,12]$} \\
\hline Georgia & 196 & 522 & 12 & 730 & {$[11,12]$} \\
\hline Germany & 11,657 & $1,60,300$ & 8,371 & $1,80,328$ & {$[11,12]$} \\
\hline Ghana & 4,653 & 1,998 & 32 & 6,683 & {$[11,12]$} \\
\hline Gibraltar & 7 & 147 & & 154 & {$[11,12]$} \\
\hline Greece & 1,333 & 1,374 & 171 & 2,878 & {$[11,12]$} \\
\hline Greenland & 1 & 11 & & 12 & {$[11,12]$} \\
\hline Grenada & 5 & 17 & & 22 & {$[11,12]$} \\
\hline Guadeloupe & 32 & 115 & 14 & 161 & {$[11,12]$} \\
\hline Guatemala & 3,108 & 258 & 58 & 3,424 & {$[11,12]$} \\
\hline Guinea & 1,582 & 1,673 & 20 & 3,275 & {$[11,12]$} \\
\hline Guinea-Bissau & 1,066 & 42 & 6 & 1,114 & {$[11,12]$} \\
\hline Guyana & 63 & 62 & 10 & 135 & {$[11,12]$} \\
\hline Haiti & 909 & 22 & 27 & 958 & {$[11,12]$} \\
\hline Honduras & 3,302 & 468 & 180 & 3,950 & {$[11,12]$} \\
\hline Hong Kong & 32 & 1,030 & 4 & 1,066 & {$[11,12]$} \\
\hline Hungary & 1,565 & 1,690 & 486 & 3,741 & {$[11,12]$} \\
\hline Iceland & 3 & 1,791 & 10 & 1,804 & {$[11,12]$} \\
\hline India & 77,172 & 57,721 & 4,024 & $1,38,917$ & {$[11,12]$} \\
\hline Indonesia & 15,497 & 5,402 & 1,372 & 22,271 & {$[11,12]$} \\
\hline Iran & 22,483 & $1,05,801$ & 7,417 & $1,35,701$ & {$[11,12]$} \\
\hline Iraq & 1,571 & 2,738 & 160 & 4,469 & {$[11,12]$} \\
\hline Ireland & 1,971 & 21,060 & 1,608 & 24,639 & {$[11,12]$} \\
\hline Isle of Man & 9 & 303 & 24 & 336 & {$[11,12]$} \\
\hline Israel & 2,285 & 14,153 & 279 & 16,717 & {$[11,12]$} \\
\hline Italy & 56,594 & $1,40,479$ & 32,785 & $2,29,858$ & {$[11,12]$} \\
\hline Ivory Coast & 1,127 & 1,219 & 30 & 2,376 & {$[11,12]$} \\
\hline Jamaica & 332 & 211 & 9 & 552 & {$[11,12]$} \\
\hline Japan & 2,317 & 13,413 & 820 & 16,550 & {$[11,12]$} \\
\hline Jordan & 228 & 471 & 9 & 708 & {$[11,12]$} \\
\hline Kazakhstan & 4,144 & 4,352 & 35 & 8,531 & {$[11,12]$} \\
\hline Kenya & 780 & 383 & 51 & 1,214 & {$[11,12]$} \\
\hline Kuwait & 15,029 & 6,117 & 156 & 21,302 & {$[11,12]$} \\
\hline Kyrgyzstan & 425 & 992 & 16 & 1,433 & {$[11,12]$} \\
\hline Laos & 5 & 14 & & 19 & {$[11,12]$} \\
\hline Latvia & 313 & 712 & 22 & 1,047 & {$[11,12]$} \\
\hline Lebanon & 400 & 688 & 26 & 1,114 & {$[11,12]$} \\
\hline Lesotho & 2 & & & 2 & {$[11,12]$} \\
\hline Liberia & 100 & 139 & 26 & 265 & {$[11,12]$} \\
\hline Libya & 33 & 39 & 3 & 75 & {$[11,12]$} \\
\hline Liechtenstein & 26 & 55 & 1 & 82 & {$[11,12]$} \\
\hline Lithuania & 422 & 1,138 & 63 & 1,623 & {$[11,12]$} \\
\hline Luxembourg & 115 & 3,767 & 110 & 3,992 & {$[11,12]$} \\
\hline Macao & 0 & 45 & & 45 & {$[11,12]$} \\
\hline Madagascar & 383 & 142 & 2 & 527 & {$[11,12]$} \\
\hline Malawi & 46 & 33 & 4 & 83 & {$[11,12]$} \\
\hline Malaysia & 1,185 & 5,945 & 115 & 7,245 & {$[11,12]$} \\
\hline Maldives & 1,223 & 144 & 4 & 1,371 & {$[11,12]$} \\
\hline Mali & 368 & 597 & 65 & 1,030 & {$[11,12]$} \\
\hline Malta & 128 & 476 & 6 & 610 & {$[11,12]$} \\
\hline Martinique & 92 & 91 & 14 & 197 & {$[11,12]$} \\
\hline Mauritania & 216 & 15 & 6 & 237 & {$[11,12]$} \\
\hline Mauritius & 2 & 322 & 10 & 334 & {$[11,12]$} \\
\hline Mayotte & 673 & 894 & 20 & 1,587 & {$[11,12]$} \\
\hline Mexico & 13,802 & 47,424 & 7,394 & 68,620 & {$[11,12]$} \\
\hline Moldova & 3,130 & 3,713 & 250 & 7,093 & {$[11,12]$} \\
\hline Monaco & 4 & 90 & 4 & 98 & {$[11,12]$} \\
\hline Mongolia & 108 & 33 & & 141 & {$[11,12]$} \\
\hline Montenegro & 0 & 315 & 9 & 324 & {$[11,12]$} \\
\hline Montserrat & 0 & 10 & 1 & 11 & {$[11,12]$} \\
\hline Morocco & 2,531 & 4,703 & 199 & 7,433 & {$[11,12]$} \\
\hline Mozambique & 143 & 51 & & 194 & {$[11,12]$} \\
\hline MS Zaandam & 7 & & 2 & 9 & {$[11,12]$} \\
\hline Myanmar & 73 & 122 & 6 & 201 & {$[11,12]$} \\
\hline Namibia & 7 & 14 & & 21 & {$[11,12]$} \\
\hline Nepal & 513 & 87 & 3 & 603 & {$[11,12]$} \\
\hline Netherlands & $\mathrm{N} / \mathrm{A}$ & $\mathrm{N} / \mathrm{A}$ & 5,822 & 45,236 & {$[11,12]$} \\
\hline New Caledonia & 0 & 18 & & 18 & {$[11,12]$} \\
\hline New Zealand & 27 & 1,456 & 21 & 1,504 & {$[11,12]$} \\
\hline Nicaragua & 63 & 199 & 17 & 279 & {$[11,12]$} \\
\hline
\end{tabular}




\begin{tabular}{|c|c|c|c|c|c|}
\hline Niger & 101 & 783 & 61 & 945 & {$[11,12]$} \\
\hline Nigeria & 5,350 & 2,263 & 226 & 7,839 & {$[11,12]$} \\
\hline North Macedonia & 443 & 1,422 & 113 & 1,978 & {$[11,12]$} \\
\hline Norway & 390 & 7,727 & 235 & 8,352 & {$[11,12]$} \\
\hline Oman & 5,800 & 1,933 & 37 & 7,770 & {$[11,12]$} \\
\hline Pakistan & 36,270 & 17,198 & 1,133 & 54,601 & {$[11,12]$} \\
\hline Palestine & 63 & 357 & 3 & 423 & {$[11,12]$} \\
\hline Panama & 4,341 & 6,279 & 306 & 10,926 & {$[11,12]$} \\
\hline Papua New Guinea & 0 & 8 & & 8 & {$[11,12]$} \\
\hline Paraguay & 544 & 307 & 11 & 862 & {$[11,12]$} \\
\hline Peru & 66,708 & 49,795 & 3,456 & $1,19,959$ & {$[11,12]$} \\
\hline Philippines & 9,918 & 3,249 & 868 & 14,035 & {$[11,12]$} \\
\hline Poland & 11,136 & 9,194 & 996 & 21,326 & {$[11,12]$} \\
\hline Portugal & 11,758 & 17,549 & 1,316 & 30,623 & {$[11,12]$} \\
\hline Qatar & 34,521 & 9,170 & 23 & 43,714 & {$[11,12]$} \\
\hline Réunion & 5,486 & 11,399 & 1,185 & 18,070 & {$[11,12]$} \\
\hline Romania & $2,27,641$ & $1,13,299$ & 3,541 & $3,44,481$ & {$[11,12]$} \\
\hline Russia & 90 & 237 & & 327 & {$[11,12]$} \\
\hline Rwanda & 40 & 411 & 1 & 452 & {$[11,12]$} \\
\hline S. Korea & 713 & 10,226 & 267 & 11,206 & {$[11,12]$} \\
\hline Saint Kitts and Nevis & 0 & 15 & & 15 & {$[11,12]$} \\
\hline Saint Lucia & 0 & 18 & & 18 & {$[11,12]$} \\
\hline Saint Martin & 4 & 33 & 3 & 40 & {$[11,12]$} \\
\hline Saint Pierre Miquelon & 0 & 1 & & 1 & {$[11,12]$} \\
\hline San Marino & 357 & 266 & 42 & 665 & {$[11,12]$} \\
\hline Sao Tome and Principe & 239 & 4 & 8 & 251 & {$[11,12]$} \\
\hline Saudi Arabia & 28,650 & 43,520 & 390 & 72,560 & {$[11,12]$} \\
\hline Senegal & 1,556 & 1,456 & 35 & 3,047 & {$[11,12]$} \\
\hline Serbia & 5,064 & 5,857 & 238 & 11,159 & {$[11,12]$} \\
\hline Seychelles & 0 & 11 & & 11 & {$[11,12]$} \\
\hline Sierra Leone & 426 & 241 & 40 & 707 & {$[11,12]$} \\
\hline Singapore & 16,717 & 14,876 & 23 & 31,616 & {$[11,12]$} \\
\hline Sint Maarten & 3 & 59 & 15 & 77 & {$[11,12]$} \\
\hline Slovakia & 180 & 1,301 & 28 & 1,509 & {$[11,12]$} \\
\hline Slovenia & 21 & 1,340 & 107 & 1,468 & {$[11,12]$} \\
\hline Somalia & 1,329 & 204 & 61 & 1,594 & {$[11,12]$} \\
\hline South Africa & 11,054 & 11,100 & 429 & 22,583 & {$[11,12]$} \\
\hline South Sudan & 641 & 6 & 8 & 655 & {$[11,12]$} \\
\hline Spain & 57,142 & $1,96,958$ & 28,752 & $2,82,852$ & {$[11,12]$} \\
\hline Sri Lanka & 458 & 674 & 9 & 1,141 & {$[11,12]$} \\
\hline St. Barth & 0 & 6 & & 6 & {$[11,12]$} \\
\hline St. Vincent Grenadines & 4 & 14 & & 18 & {$[11,12]$} \\
\hline Sudan & 3,197 & 458 & 165 & 3,820 & {$[11,12]$} \\
\hline Suriname & 1 & 9 & 1 & 11 & {$[11,12]$} \\
\hline Sweden & 24,490 & 4,971 & 3,998 & 33,459 & {$[11,12]$} \\
\hline Switzerland & 730 & 28,100 & 1,906 & 30,736 & {$[11,12]$} \\
\hline Syria & 41 & 41 & 4 & 86 & {$[11,12]$} \\
\hline Taiwan & 20 & 414 & 7 & 441 & {$[11,12]$} \\
\hline Tajikistan & 1,582 & 1,301 & 46 & 2,929 & {$[11,12]$} \\
\hline Tanzania & 305 & 183 & 21 & 509 & {$[11,12]$} \\
\hline Thailand & 63 & 2,921 & 56 & 3,040 & {$[11,12]$} \\
\hline Timor-Leste & 0 & 24 & & 24 & {$[11,12]$} \\
\hline Togo & 228 & 141 & 12 & 381 & {$[11,12]$} \\
\hline Trinidad and Tobago & 0 & 108 & 8 & 116 & {$[11,12]$} \\
\hline Tunisia & 86 & 917 & 48 & 1,051 & {$[11,12]$} \\
\hline Turkey & 33,793 & $1,18,694$ & 4,340 & $1,56,827$ & {$[11,12]$} \\
\hline Turks and Caicos & 1 & 10 & 1 & 12 & {$[11,12]$} \\
\hline UAE & 14,184 & 15,056 & 245 & 29,485 & {$[11,12]$} \\
\hline Uganda & 130 & 68 & & 198 & {$[11,12]$} \\
\hline UK & $\mathrm{N} / \mathrm{A}$ & $\mathrm{N} / \mathrm{A}$ & 36,793 & $2,59,559$ & {$[11,12]$} \\
\hline Ukraine & 13,261 & 7,108 & 617 & 20,986 & {$[11,12]$} \\
\hline Uruguay & 129 & 618 & 22 & 769 & {$[11,12]$} \\
\hline USA & $11,35,434$ & $4,51,702$ & 99,300 & $16,86,436$ & {$[11,12]$} \\
\hline Uzbekistan & 586 & 2,565 & 13 & 3,164 & {$[11,12]$} \\
\hline Vatican City & 10 & 2 & & 12 & {$[11,12]$} \\
\hline Venezuela & 849 & 262 & 10 & 1,121 & {$[11,12]$} \\
\hline Vietnam & 58 & 267 & & 325 & {$[11,12]$} \\
\hline Western Sahara & 3 & 6 & & 9 & {$[11,12]$} \\
\hline Yemen & 170 & 10 & 42 & 222 & {$[11,12]$} \\
\hline Zambia & 577 & 336 & 7 & 920 & {$[11,12]$} \\
\hline Zimbabwe & 27 & 25 & 4 & 56 & {$[11,12]$} \\
\hline
\end{tabular}




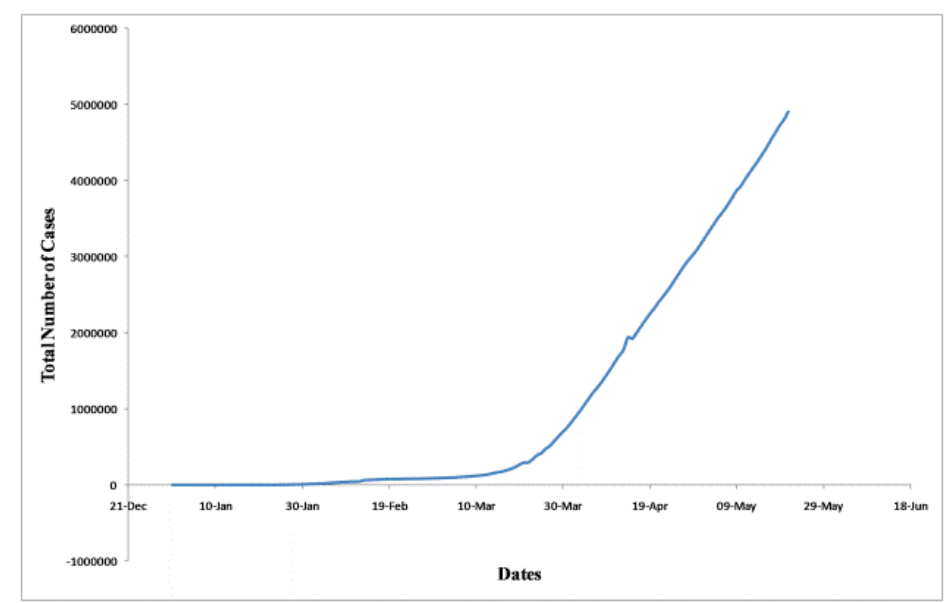

Fig. 5: Cumulative cases of COVID-19 worldwide from december 31, 2019 to May 24, 2020 (self made)

\section{COVID-19 cases worldwide}

As of May 24, 2020, the outbreak of the coronavirus disease (COVID19) has been confirmed in around 203 countries or territories. The virus had infected 55,00,679 people worldwide, and around $3,46,721$ people were died because of this viral infection. The most severely affected countries include the USA $(16,86,436)$, Brazil $(3,65,213)$, Russia $(3,44,481)$, Spain $(2,82,852)$ and UK $(2,59,559)$ $[11,12]$. Complete worldwide country wise data of total coronavirus (COVID-19) active cases, recoveries and deaths till May 24, 2020 is illustrated in table 1.

\section{Pathogenicity of COVID-19}

\section{Structure of coronavirus}

Most common viruses can be genetically divided into two types. One type of viruses has DNA (Deoxyribonucleic acid) as genetic material and the other type have RNA as genetic material. The RNA viruses can further divided into two types: first type contains ssRNA (Single stranded ribonucleic acid) and other type contains dsRNA (Doublestranded ribonucleic acid) as genetic material [26-28].

In current scenario, the most dangerous and recently discovered virus (2019 origin) is Coronavirus, which is one such example of ssRNA viruses. The RNA present in these Coronoavirus mainly consists of RNA Synthesis materials, nanostructural polyproteins, viral polymerase and the genome. The genome of this RNA virus mainly consists of four basic structural proteins like envelop, spike, nucleocapsid and membrane. Such coronavirus may also contain some other types of helper proteins. The length of these coronaviruses is highly dependent on the nanostructuralpolyproteins, viral polymerase and the genome present in the virus $[29,30]$. There are two most widely known strains, named as SARS and MERS, which have caused more than 800 deaths. The size of the virus varies as per the diameter between $80-120 \mathrm{~nm}$. The structure of SARS CoV-2 is shown in fig. 6.

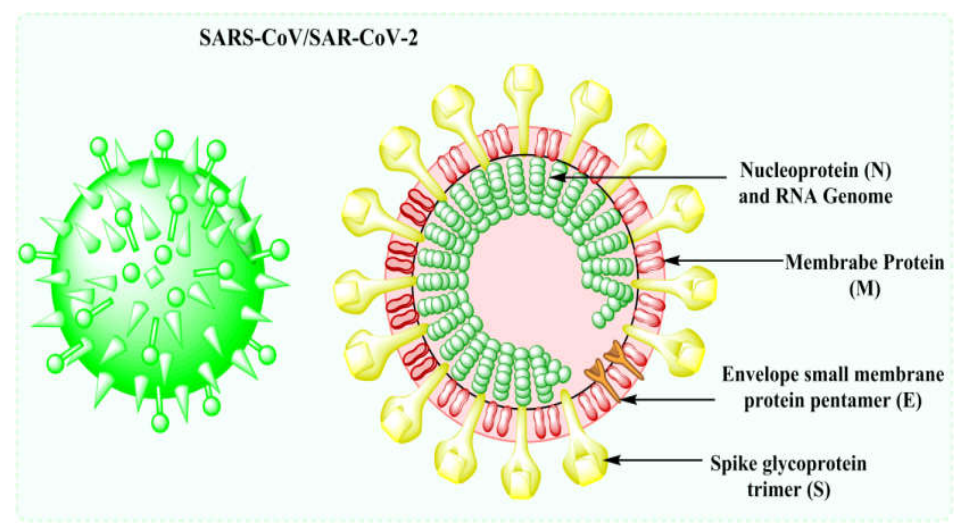

Fig. 6: Structure of novel SARS-Cov2 (self-made)

Basically, coronaviruses are divided into four categories $\alpha$ coronavirus $(\alpha$-COV), $\beta$-coronavirus $(\beta$-COV), $\delta$-coronavirus $(\delta$ COV), $\gamma$-coronavirus $(\gamma$-COV) $[8,31,32]$. Alpha and Beta coronavirus are mainly related with infections in mammals, whereas Gamma-and Delta coronavirus predominantly (not entirely) infect birds [33]. The examples of alpha coronaviruses are human coronavirus-229E and virus-NL63 and of beta coronaviruses are human coronavirus-0C43 and virus-HKU1 and these are recognized human pathogens and are accountable for the worldwide occurrence of the common cold in humans $[34,35]$. It is evident from the study that up to $20 \%$ of tests in humans accompanied with respiratory disease have an acute infection with these viruses. Human Corona Virus-229E was first to extricate in 1967 and only 65\% nucleotide identity was shared with another human alpha coronavirus, Human Corona Virus-NL63 was first isolated in 2003 from a child $(7 \mathrm{mo})$ suffering from respiratory diseases (bronchiolitis and conjunctivitis) [36]. However, the majority of infections with Human Corona Viruses cause only mild respiratory tract illness. Human Corona Viruses are responsible for onset of disease, especially, but not completely in infants and immune-suppressed patients. Coronavirus not only occurs in the respiratory tract but can be detected in stool $[22,37]$ 


\section{Multiplication/replication of virus in host body}

When the coronavirus enters the host body then it gradually multiply and shows its genomic adaptation and hence is able to survive in the host body. Each viral cell shows the different types of genomic adaptation as compared to other virus. Various steps by which the virus expands in the body are mentioned below [38-44].

Firstly, there is an interaction between sensitive human cells with spike protein of the virus takes place. Afterward, it enters into sensitive human cells and Corona virus Genome encoding occurs. This accelerates gene expression in the virus; these genes encodes functional proteins, which helps in accommodating Corona Viruses to their human host. Such type of genome changes resulting from recombination, gene exchange, gene insertion, or deletion are very frequent among CoronaViruses and this further will take place in future outbreaks as in past epidemics. As a result of the studies, the Corona Virus subfamily is rapidly expanding with new generation sequencing applications that improves the detection and definition of novel Corona Virus species. In conclusion, Corona Virus classification is continually changing. According to the most recent classification of The International Committee on Taxonomy of Viruses (ICTV), there are four genera of thirty eight unique species of this virus as given in fig. 7 .

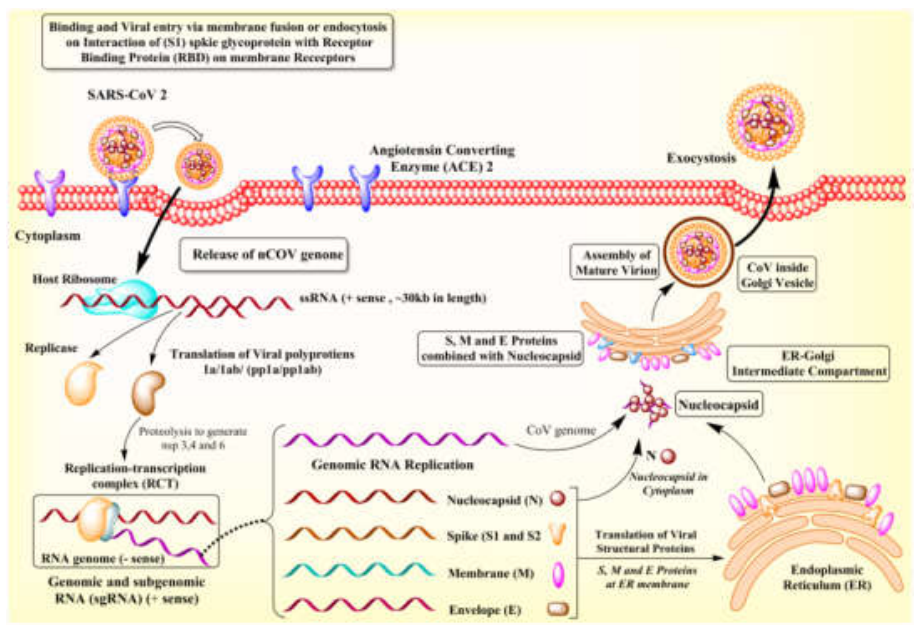

Fig. 7: Replication of corona virus (self made)

After entering the cell, the viral RNA manifests itself in the cytoplasm. Genomic RNA in the coronavirus is encapsulated and polyadenylated. This RNA encodes various structural and nonstructural polypeptide genes. These polyproteins are split by proteases that exhibit chymotrypsin-like activity. The resulting complex drives/increases more RNA production by both the processes (replication and transcription). Full-length RNA copies of the genomes are massively produced during process of replication. Additionally, it is used as a template for RNA genomes of full length A subset of 7-9 sub-genomic RNAs are produced during transcription and encoding of all structural proteins occursby discontinuous transcription. Viral nucleo-capsids are combined from RNA (genomic) and in the cytoplasm (R-protein) and then are budded into endoplasmic reticulum (ER) lumen, by the process of exocytosis, the new virions are escaped out from the diseased cell and can contaminate various organs like liver, kidney intestines, $\mathrm{T}$ lymphocytes etc., as well as the respiratory system.

\section{Risk factors of novel coronavirus}

Risk factors for COVID-19 (Human Corona Virus-2019) are still largely unknown; however, it is believed that the virus is transmitted to humans via contaminated live animals (snakes, civet cats). All three $\beta$ coronaviruses were developed via zoonotic communication. Risk factors for zoonotic transmission of MERS and SARS was direct contact through infectious animals. The suspected reservoir hosts are currently believed to be bats, similar to the SARS epidemic [45-53]

\section{First evidence-animals to human}

It is based on the numerous infected people that were barren to market of animals in Wuhan. In the market, the alive animals are sold daily; and was found that this was a zoonotic origin of the COVID-19. WMHC (Wuhan Municipal Health Commission) recorded the 27 positive cases of pneumonia on $12^{\text {th }}$ December, 2019 and out of them, 7 cases were critical. Most of the patients were having recent history of Seafood Wholesale Market in Wuhan. In this market, various animals and reptiles such as bats, snake and poultry animals were also traded. This was known to be main cause of origin of new type of coronavirus, this pandemic is growing very faster and provisionally called as COVID-19 by WHO (World Health Organization).

\section{Second evidence-snakes to humans}

Various efforts were made in search of intermediate carriers and reservoir host. Initial reports were resulted that two species of snakes are reservoir of the COVID-19 possibly. Although, no evidence was found of coronavirus reservoirs other than bird and mammals.

\section{Third evidence-mammals (bats) to humans}

The genomic sequence of this COVID-19 is $88 \%$ identical with SARS, which is a bat originated disease indicates that the mammals are mostly linked between COVID-19 and humans.

\section{Fourth evidence-human to human}

Many cases have been reported and suggested that transmission between people (person to person) spreads COVID-19 infection. It is anticipated by the cases occurred within families and among the people who did not explore animal market in Wuhan. Primarily, person-toperson transmission takes place through direct contact or by coughing or sneezing (droplet spreading) from an infected individual.

\section{Fifth evidence-human mother to child}

A small study was conducted on a pregnant women (third trimester) who was infected with coronavirus. There was no evidence that the transmission occurred from mother to child. Although all pregnant mothers went through surgery (caesarean), it remains unclear whether transmission can takes place during normal vaginal delivery. Pregnant mothers are comparatively more susceptible to this infection so this study is important.

\section{Modes of transmission}

Initially, it was presumed that COVID-19 got transmitted from the bat (due to similar genome sequence) to humans via an unknown intermediate $[54,55]$. However, subsequent cases showed that 
human to human transmission of COVID-19 is more viable [56] Since COVID-19 has become a pandemic and international health emergency, clearly, it is evident that there is a lack of understanding the various means of COVID-19 transmission [57, 58]. Although, the COVID-19 transmission modes have already been discussed by various national and international agencies such as WHO and National Centre for Disease Control, Directorate General of Health Services Ministry of Health and Family Welfare, Government of India, the increasing number of COVID-19 patients showed that people are finding hard to understand this information and difficult to adhere. To control the further spread of COVID-19, people should be informed about various methods by which this contagious disease can transmit $[59,60]$. Besides common people, it is very important for health care providers to know COVID-19 dissemination routes as they are constantly dealing with COVID-19 infected patients [61]. Fig. 8 shows potential transmission routes for novel coronavirus (COVID-19). A person may develop COVID-19 infection by:

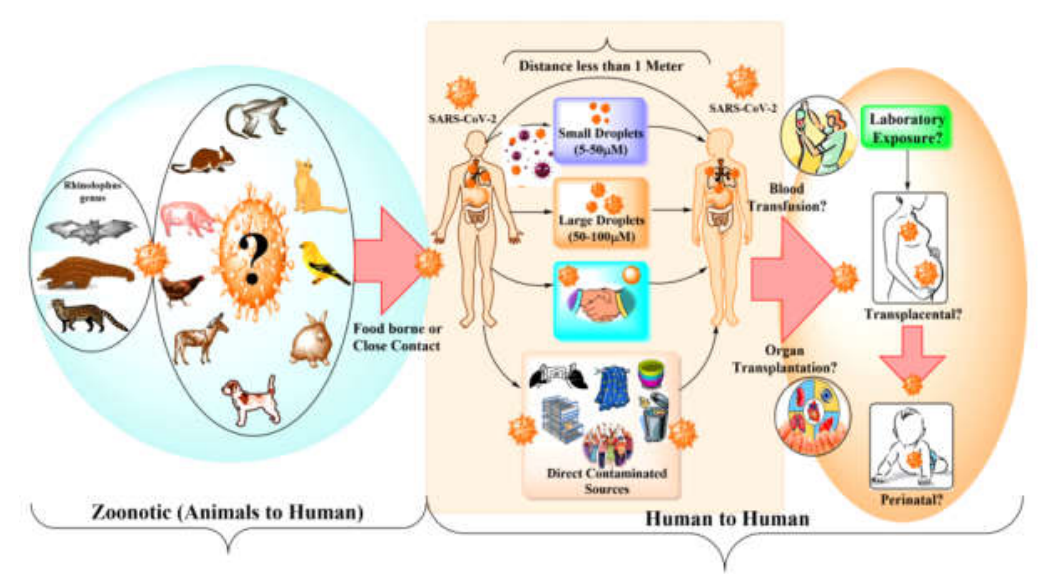

Fig. 8: Potential transmission route for novel coronavirus (COVID-19) (self-made)

\section{Contact transmission}

By making a direct contact with contaminated animate (human or animals) and/or inanimate objects (water, food, stethoscope or thermometer) COVID-19 can spread $[55,59]$. It can also be indirectly transmitted via an intermediate person or object e.g. without maintaining proper hand hygiene in between touching an infected body site of a patient and then a normal person [62,63]. Sometimes, it may spread by contacting asymptomatic carriers as the infected person may not be aware of harbouring the virus $[64,65]$. The direct transmission was reported in an observational study from Zhejiang province, where 62 patients were reported to develop laboratory positive COV-2 infection via direct exposure to already confirm COVID-19 infected individuals [66].

\section{Droplet transmission}

Chances of COVID-19 infection are more likely to occur in people who are in the vicinity of 1 metre to infected individual as droplets (containing virus) released by an infected person via coughing and sneezing (excretions/secretions of the gastrointestinal tract, respiratory tract, blood or any other body fluid) may be inhaled by healthy individuals [67]. Even talking with an infected person may spread the CVOID-19 [68].

\section{Airborne dissemination}

Very small airborne particles (containing virus) that can travel via air currents which can be inhaled by susceptible individuals and thus may contribute to COVID-19 transmission. Transmission under specific settings such as bronchoscopy, cardio pulmonary resuscitation, manual ventilation before intubation, endotracheal intubation and tracheostomy which lead to the production of aerosols may also possible (WHO report dated 27 March, 2020). A person with compromised immunity such as aged people, pregnant women, and persons taking immunosuppressive and chemotherapeutic agents may have higher chances to develop COVID-19 infection [69].

\section{Sign and symptoms}

COVID-19 is a respiratory viral infection which leads to the development of mild to moderate clinically diagnosed symptoms after 2-14 d of its exposure [70]. As suggested by WHO, usually, the symptoms get resolve without any special treatment; however, person above the age of 60 frequently requires hospitalization and special care [71]. WHO has reported the development of fever, dry cough and tiredness as common diagnostic characters along with other symptoms including aches, breathlessness, runny nose, sore throat and diarrhoea for COVID-19 infection. The clinical characteristics varied from patient to patient and 138 hospitalized patients showed the development of fever, fatigue, dry cough, anorexia, myalgia, dyspnea, expectoration, pharyngalgia, diarrhea, nausea, dizziness, vomiting and abdominal pain [72]. These symptoms were consistent with another COVID-19 patients $[18,73$, 74]. Also, the computed tomography scans showed bilateral lung ground-glass opacity in the majority of the cases [75]. The various symptoms are shown diagrammatically in fig. 9.

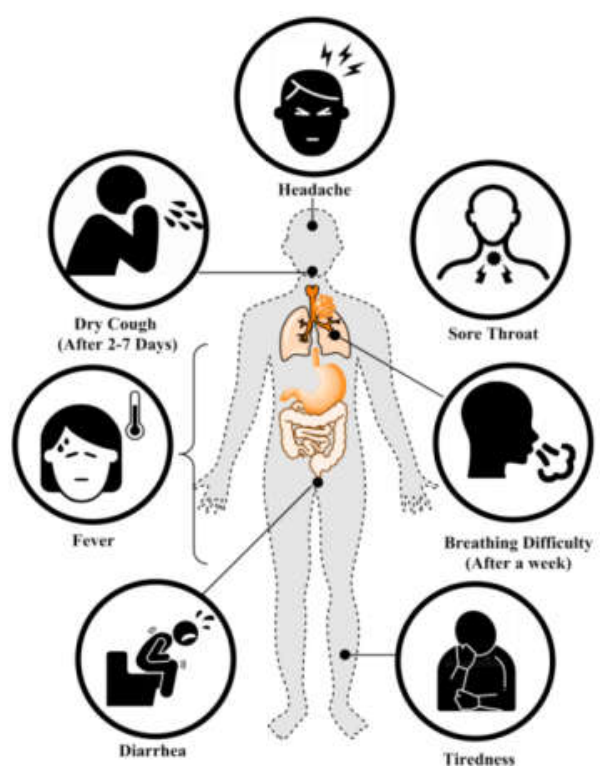

Fig. 9: Symptoms of coronavirus (self-made) 
Based on the severity of the disease, the report from Chinese Center for Disease Control and Prevention [76] has divided the clinical manifestations of COVID-19 into:

\section{Mild disease}

These symptoms were found in $81 \%$ of the clinical cases (out of 72314 total cases). This included non-pneumonia and mild pneumonia symptoms.

\section{Severe disease}

These symptoms were diagnosed in 14\% of the cases (out of 72314 total cases). The manifestations included were dyspnea, impaired respiration (frequency $\geq 30 / \mathrm{min}$ ), lung infiltrates $>50 \%$, blood oxygen saturation $\leq 93 \%$ and partial pressure of arterial oxygen to fraction of inspired oxygen ratio $<300$ within 24 to $48 \mathrm{~h}$.

\section{Critical disease}

These symptoms include septic shock, respiratory failure, and multiple organ dysfunction constitutes only $5 \%$ of the total COVID19 cases (out of 72314 total cases).

\section{Treatment of corona virus-2019}

There is no antiviral treatment specifically recommended for COVID19 till date and there is no vaccine available currently. The preventive treatment available is symptomatic and oxygenated therapy which possesses a major treatment effects in patients with severe infection. Ventilation (mechanical) is an important respiratory failure while hemodynamic support system is an important for the management of septic shock
On January 28, 2020, the WHO released a document summarizing WHO guidelines and scientific evidences were derived from the treatment of previous epidemics from (Human coronavirus) HCoVs. This document addresses measure for recognizing and sorting patients with severe acute respiratory disease, strategies for infection prevention and control, early supportive therapy and monitoring, a guideline for laboratory diagnosis, management of respiratory failure and ARDS, management of septic shock, prevention of complications, treatments, and considerations for pregnant patients.

Amidst other therapeutic tactics, the systemic corticosteroids are not recommended for the treatment of pneumonia (viral) and respiratory disease such as acute respiratory distress syndrome (ARDS). Additionally, unselective antibiotic administration should be avoided, whilst some centers proposed it for treating Covid-19. As per WHO, FDA and Centers for Disease Control and Prevention (CDC), there is no specific vaccine or medication that is approved or proven to treat COVID-19 infection. For individuals having mild symptoms are suggested to stay home quarantine. As of $30^{\text {th }} \mathrm{March}$ 2020, due to lack of specific treatment, the major focus for treating the hospitalised COVID-19 patients is based on their clinical manifestation. Based on the invitro and/or preclinical studies, several clinical trials are under progress to evaluate the efficacy of anti-viral drugs in COVID-19 infected patients. Some guidelines have been provided for Covid-19 related to Prevention, Diagnosis and Treatment issued and approved by the National Health Commission (NHC) of the People's Republic of China for the treatment (tentative) of COVID-19 suggests the use of different drugs with their dose strengths against COVID 19 as shown in table 2 [77-79].

Table 2: List of anti-viral drugs to treat COVID-19 (as per the National Health Commission (NHC) of the People's Republic of China)

\begin{tabular}{|c|c|c|c|c|c|}
\hline S. No. & Drug & $\begin{array}{l}\text { Route of } \\
\text { administration }\end{array}$ & Dose & $\begin{array}{l}\text { Treatment } \\
\text { duration }\end{array}$ & Reference \\
\hline 1. & Lopinavir/Ritonavir & Oral & $200 \mathrm{mg} / 50 \mathrm{mg} /$ capsule, 2 capsules twice daily & Maximum $10 \mathrm{~d}$ & [79] \\
\hline 2. & IFN- $\alpha$ & Vapour inhalation & 5 million U twice daily & Maximum $10 \mathrm{~d}$ & [79] \\
\hline 3. & Chloroquine phosphate & Oral & $500 \mathrm{mg}$ twice a day & Maximum $10 \mathrm{~d}$ & [79] \\
\hline 4. & Ribavirin & Intravenous & $\begin{array}{l}500 \mathrm{mg} \text { twice or thrice a day in combination } \\
\text { with lopinavir/ritonavir or IFN- } \alpha\end{array}$ & Maximum $10 \mathrm{~d}$ & [79] \\
\hline 5. & Arbidol & Oral & $200 \mathrm{mg} 3$ times a day & Maximum $10 \mathrm{~d}$ & [79] \\
\hline
\end{tabular}

As of $3^{\text {rd }}$ May, 2020, on the basis of subsequent uncontrolled clinical trials, Ministry of Health and Family Welfare, Directorate General of Health Services, Government of India issued some important guidelines (clinical) for the management of COVID-19. It recommends the use of hydroxychloroquine (200 mg twice a day for $4 \mathrm{~d}$ ) and azithromycin ( $500 \mathrm{mg}$ once a day for $5 \mathrm{~d}$ ) combination for the treatment of patients with severe COVID19 clinical manifestation. These guidelines were revised on 31 ${ }^{\text {st }}$ March, 2020. Earlier The Ministry of Health and family Welfare recommended the use of combination (Lopinavir/ritonavir) at same doses as mentioned in table 1 for 7 or $14 \mathrm{~d}$ against COVID-19 in laboratory-confirmed severe cases. However, this drug combination poses side-effects that sometimes lead to its discontinuation and, thus, limits the usage [80]

So far reports has evidenced the use of some antiviral drugs that may have potential thus may play an important role in managing COVID-19 infection [22]. A brief about the mode of action of these drugs is given below:

\section{Chloroquine}

An anti-malarial and autoimmune disease drug (Chloroquine), which is recently reported as a potential broad-spectrum antiviral drug. It was found that chloroquine effectively suppresses and clinically applicable against recently emerged novel coronavirus (COVID-19) [22, 81-84]

\section{Lopinavir-ritonavir}

A protease inhibitor, the combination of these drugs easily interfere with replication and HIV synthesis (Human immunodeficiency virus). It is highly responsible for the production of virus particles (immature and non-infectious). It is evident that the combination of LopinavirRitonavir easily binds to the enzyme (endopeptidase C30) of SARSCoV2 protease. Several reports are evident that lopinavir-ritonavir alone treated or in combination with other antiviral drugs improved the results of severe patients with SARS or MERS [22, 85-90].

\section{Remdesivir}

A nucleoside analogue GS-5734 named remdesivir was first revealed to inhibit SARS-CoV and MERS-CoV. Recently, in vitro study reported that remdesivir at low-micromolar concentration; it potently blocked SARS-CoV2 infection and high selectivity index (SI). Moreover, it is beneficial for the treatment of COVID-19 pneumonia [22, 91, 92].

\section{Hydroxychloroquine}

Hydroxychloroquine sulfate, a Chloroquine derivative, was first synthesized in 1946 by attaching a hydroxyl group into Chloroquine. It was experimentally demonstrated in 4 animals and resulted to be much less toxic $(\sim 40 \%)$ as compared to Chloroquine. Hydroxychloroquine is widely available for the treatment of autoimmune diseases (systemic lupus erythematosus and rheumatoid arthritis). Clinically, it was investigated and found that the higher concentrations of cytokines were observed in the plasma of critically infected patients with SARS-CoV-2. It was suggesting that cytokines were associated with disease extremity. Hydroxychloroquine is a safer and an effective anti-inflammatory drug as compared to direct antiviral activity as it decreases the cytokines production [22, 93-95].

\section{Tocilizumab}

It can bind interleukins (sIL-6R) which are soluble and membrane bound (IL-6R), which further inhibits signal transduction. Currently, 
it used in rheumatoid arthritis and immune-modulating agents are used in some protocols. An interleukins (IL-6) blocker; Tocilizumab is used to treat patients with severe and critical COVID-19. Clinical data exhibited that symptoms and changes in CT opacity were immediately improved with administration of tocilizumab. Therefore, it could be a suitable and efficient therapeutic treatment of COVID-19 [22, 96]
Simultaneously various major pharmaceutical companies are working on the development of vaccines to combat current COVID-19.

\section{Drugs under clinical trials}

Various companies have initiated the clinical trials of possible drug candidates, which would be effective in managing COVID-19 infection, as shown in table 3 [97].

Table 3: Drugs or vaccines against COVID-19 under clinical trials

\begin{tabular}{llll}
\hline Organization & Target & Clinical trial phase & Reference \\
\hline Sanofi & Plaquenil & Preclinical & {$[97]$} \\
Pfizer & New mRNA vaccine & Preclinical & {$[97]$} \\
GohnsonandGohnson & Covid-19 vaccine & Preclinical & {$[97]$} \\
Regeneron & Monoclonal antibody therapy & Preclinical & {$[97]$} \\
Takeda & Polyclonal antibody therapy & Preclinical & {$[97]$} \\
Hoth therapeutics & Self-assembling vaccine (SAV) & Preclinical & {$[97]$} \\
Arcturus therapeutics & Covid-19 vaccine & Preclinical & {$[97]$} \\
GSK & Covid-19 vaccine & Preclinical & {$[97]$} \\
Inovio & Covid-19 vaccine & Preclinical & {$[97]$} \\
CanSinoBIO & Covid-19 vaccine & Phase-I & {$[97]$} \\
Moderna & mRNA-1273 & Phase-I & {$[97]$} \\
Vaccitech & Iopinavir/ritonavir combination & Phase-IIb & Phase-III \\
Gilead & Remdesivir & & {$[97]$} \\
\hline
\end{tabular}

\section{Preventive measures for novel coronavirus}

Till date there is no vaccination available against COVID-19. For now, the most common term used by the various Government Health Authorities is "Prevention Is Better than Cure". Some preventive measures have been suggested by the WHO which will help in diminishing the spread of coronavirus. Some of these preventive advisory methods are mentioned which includes social distancing, abstain a close contact with a person who is suffering from fever and cough, maintain a distance of at least 1 meter from a person who is coughing or sneezing, refrain touching body cavities such as eyes, nose, mouth, use N95 masks, eye-protective (goggles), disposable gown raincoat (long sleeved), disposable socks and gloves, dispose tissue safely after coughing or sneezing, frequently cleaning and sanitizing the touched objects and surfaces with the help of spray or wipe. The Centers for Disease Control (CDC) states that wearing a mask is not important unless the healthy individual is caring an infected person. It also recommended that only infected person should wear masks to prevent the spread, washing hands frequently with soap and water for 20 seconds, use of sanitizer (alcohol based) if soap and water is not available., immediately seek medical surveillance, if one is suffering from fever and cough, travel advisory is surely set out by the advisory, during incubation period, preoxygenation for $5 \mathrm{~min}$ should be executed with the help of continuous positive airway pressure method $[98,99]$. Till now there is no vaccine against COVID-19 but social distancing is the only method to break the transmission chain of this virus (fig. 10).

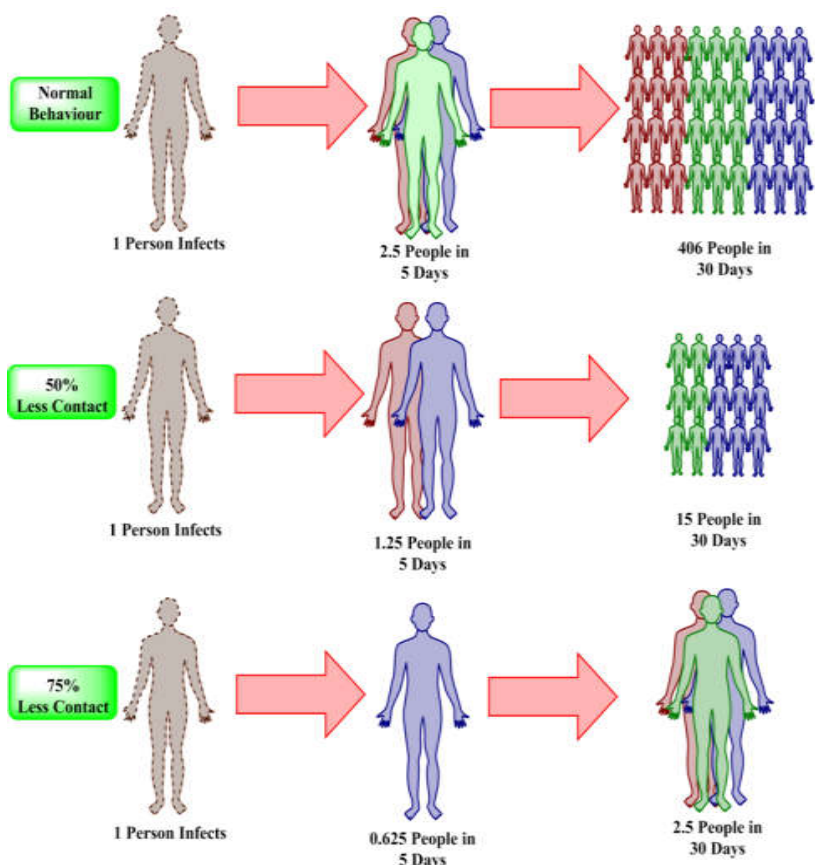

Fig. 10: Diagrammatic representation of social distancing and its effectiveness (self made) 


\section{Future prospectives}

Based on the experience of COVID-19 pandemic, effective measures should be developed to counter the possible future zoonotic $\mathrm{CoV}$ epidemic. In this context, extensive studies including screening, isolation and identification on viruses, which may be associated with such outbreaks, are required. Advanced studies in development of antiviral agents against such emerging viral infections are certainly required. Till date, various control measures as notified by National and International health agencies should be taken by the public to further prevent the spread of COVID-19.

\section{CONCLUSION}

As of now, due to lack of proven effective treatment, social distancing is the only appropriate mean to avoid the spread of COVID-19 infection. Developing an effective treatment for COVID-19 is primarily important and the research strategies focusing on the designing and evaluating such therapeutic regimens should be conducted at earliest. Even the various Clinical Trial authorities should consider these studies under fast-track program wherever applicable to develop the drug and subsequently halt the COVID-19 pandemic.

\section{ACKNOWLEDGEMENT}

The authors are thankful to Dr. Madhu Chitkara, Vice-Chancellor, Chitkara University; Dr. Ashok Chitkara, Chancellor, Chitkara University; Dr. Sandeep Arora, Director, Chitkara College of Pharmacy for providing necessary facilities and support.

\section{FUNDING}

Nil

\section{AUTHORS CONTRIBUTIONS}

All the authors have contributed equally.

\section{CONFLICT OF INTERESTS}

The authors declared no conflicts of interest.

\section{REFERENCES}

1. Lai CC, Shih TP, Ko WC, Tang HJ, Hsueh PR. Severe acute respiratory syndrome coronavirus 2 (SARS-CoV-2) and corona virus disease-2019 (COVID-19): the epidemic and the challenges. Int J Antimicrob Agents 2020;55:105924.

2. Gralinski LE, Menachery VD. Return of the coronavirus: 2019nCoV. Viruses 2020;12:135.

3. Liu C, Zhou Q, Li Y, Garner LV, Watkins SP, Carter LJ, et al Research and development on therapeutic agents and vaccines for COVID-19 and related human coronavirus diseases. ACS Cent Sci 2020;6:315-31.

4. Carlos WG, Dela Cruz CS, Cao B, Pasnick S, Jamil S. Novel wuhan (2019-nCoV) coronavirus. Am J Respir Crit Care Med Vol 2020;201:P7-8.

5. Lu H, Stratton CW, Tang YW. Outbreak of pneumonia of unknown etiology in wuhan china: the mystery and the miracle. J Med Virol 2020;92:401-2.

6. Wang C, Horby PW, Hayden FG, Gao GF. A novel coronavirus outbreak of global health concern. Lancet 2020;395:470-3.

7. Lee A. Wuhan novel coronavirus (Covid-19): why global control is challenging?. Public Health 2020;179:A1-2.

8. Chen Y, Liu Q, Guo D. Emerging coronaviruses: genome structure, replication, and pathogenesis. J Med Virol 2020;92:418-23

9. Seah I, Su X, Lingam G. Revisiting the dangers of the coronavirus in the ophthalmology practice. Eye 2020;34:1155-7.

10. Hassan S, Sheikh FN, Jamal S, Ezeh JK, Akhtar A. Coronavirus (COVID-19): a review of clinical features, diagnosis, and treatment. Cureus 2020;12:e7355.

11. Statista. Covid-19/Coronavirus; 2020. Available from: https://www.statista.com/page/covid-19-coronavirus. [Last accessed on 24 May 2020]

12. World Health Organization (WHO). Coronavirus disease (COVID-19) pandemic. Coronavirus disease (COVID-19) outbreak situation; $2020 . \quad$ Available from: https://www.who.int/emergencies/diseases/novelcoronavirus-2019. [Last accessed on 24 May 2020]

13. Dhama K, Sharun K, Tiwari R, Sircar S, Bhat S, Malik YS, et al. Coronavirus disease 2019-COVID-19. Preprints 2020:2020030001.

14. Sun J, He WT, Wang L, Lai A, Ji X, Zhai X, et al. COVID-19: epidemiology, evolution, and cross-disciplinary perspectives. Trends Mol Med 2020;26:483-95.

15. Munster VJ, Koopmans M, van Doremalen N, van Riel D, de Wit E. A novel coronavirus emerging in China-key questions for impact assessment. N Engl J Med 2020;382:692-4.

16. El Zowalaty ME, Jarhult JD. From SARS to COVID-19: A previously unknown SARS-CoV-2 virus of pandemic potential infecting humans-call for a one health approach. One Health 2020;9:100124.

17. Ren SY, Gao RD, Chen YL. Fear can be more harmful than the severe acute respiratory syndrome coronavirus 2 in controlling the corona virus disease 2019 epidemic. World J Clin Cases 2020;8:652.

18. Chang D, Lin M, Wei L, Xie L, Zhu G, Cruz CS, et al. Epidemiologic and clinical characteristics of novel coronavirus infections involving 13 patients outside Wuhan, China. JAMA 2020;323:1092-3.

19. Rothan HA, Byrareddy SN. The epidemiology and pathogenesis of coronavirus disease (COVID-19) outbreak. J Autoimmun 2020;109:102433.

20. Wu JT, Leung K, Leung GM. Nowcasting and forecasting the potential domestic and international spread of the 2019-nCoV outbreak originating in Wuhan, China: a modelling study. Lancet 2020;395:689-97.

21. Wang J, Wang Z. Strengths, weaknesses, opportunities and threats (swot) analysis of china's prevention and control strategy for the covid-19 epidemic. Int J Environ Res Public Health 2020;17:2235.

22. Li H, Liu SM, Yu XH, Tang SL, Tang CK. Coronavirus disease 2019 (Covid-19): Current status and future perspective. Int J Antimicrob Agents 2020;55:105951.

23. Chan JF, Yuan $\mathrm{S}$, Kok $\mathrm{KH}$, To $\mathrm{KK}$, Chu $\mathrm{H}$, Yang J, et al. A familial cluster of pneumonia associated with the 2019 novel coronavirus indicating person-to-person transmission: a study of a family cluster. Lancet 2020;395:514-23.

24. Cheng ZJ, Shan J. 2019 Novel coronavirus: where we are and what we know. Infection 2020;48:155-63.

25. Xinhua; 2020. Available form: http://www.xinhu anet.com/politics/2020-01/28/c_1125506707.htm. [Last accessed on 24 May 2020]

26. Pan F, Ye T, Sun P, Gui S, Liang B, Li L, et al. Time course of lung changes on chest CT during recovery from 2019 novel coronavirus (COVID-19) pneumonia. Radiology 2020;295:200370.

27. Callanan J, Stockdale SR, Shkoporov A, Draper LA, Ross RP, Hill C. RNA phage biology in a metagenomic era. Viruses 2018; 10:386.

28. Guo R, Shang P, Carrillo CA, Sun Z, Lakshmanappa YS, Yan X, et al. Double-stranded viral RNA persists in vitro and in vivo during prolonged infection of porcine reproductive and respiratory syndrome virus. Virology 2018;524:78-89.

29. Chan JF, Kok KH, Zhu Z, Chu H, To KK, Yuan S, et al. Genomic characterization of the 2019 novel human-pathogenic coronavirus isolated from a patient with atypical pneumonia after visiting Wuhan. Emerg Microbes Infect 2020;9:221-36.

30. Fuenmayor J, Godia F, Cervera L. Production of virus-like particles for vaccines. New biotechnol 2017;39:174-80.

31. Dong N, Yang X, Ye L, Chen K, Chan EW, Yang M, et al. Genomic and protein structure modelling analysis depicts the origin and infectivity of $2019-n C o V$, a new coronavirus which caused a pneumonia outbreak in Wuhan, China. bioRxiv 2020. https://doi.org/10.1101/2020.01.20.913368

32. Wang LS, Wang YR, Ye DW, Liu QQ. A review of the 2019 novel coronavirus (COVID-19) based on current evidence. Int J Antimicrob Agents 2020;55:105948.

33. Shereen MA, Khan S, Kazmi A, Bashir N, Siddique R. COVID-19 infection: origin, transmission, and characteristics of human coronaviruses. J Adv Res 2020;24:91-8. 
34. Wang Y, Li X, Liu W, Gan M, Zhang L, Wang J, et al. Discovery of a subgenotype of human coronavirus NL63 associated with severe lower respiratory tract infection in China, 2018. Emerg Microbes Infect 2020;9:246-55.

35. Ladimo MP, Irwan I. MERS-CoV (Middle East Respiratory Syndrome-Corona Virus) menggegerkan dunia timur. J Health Sci: Gorontalo J Health Sci Community 2020;4:18-28.

36. Chaudhary NK. Outbreak of coronavirus disease (COVID-19). J Chitwan Med Coll 2020;10:1-2.

37. Malik YS, Sircar S, Bhat S, Vinodhkumar OR, Tiwari R, Sah R, et al. Emerging coronavirus disease (covid-19), a pandemic public health emergency with animal linkages: current status update. Preprints 2020;90:2020030343.

38. Zhang L, Liu Y. Potential interventions for novel coronavirus in China: a systematic review. J Med Virol 2020;92:479-90.

39. Rasool A, Ishfaq S, Uqab B. Novel coronavirus (2019-nCoV) Outbreak in China: From Local Epidemics to Global Pandemics; 2020.

40. Schoeman D, Fielding BC. Coronavirus envelope protein: current knowledge. Virol J 2019;16:69.

41. Deng X, Volk A, Chen Y, Kesely KR, Hackbart M, Mettelman RC, et al. Coronavirus interferon antagonists differentially modulate the host response during replication in macrophages. bioRxiv 2019. https://doi.org/10.1101/782409

42. Abassi ZA, Skorecki K, Heyman SN, Kinaneh S, Armaly Z. Covid19 infection and mortality-A physiologist's perspective enlightening clinical features and plausible interventional strategies. Am J Physiol Lung Cell Mol Physiol 2020. https://doi.org/10.1152/ajplung.00097.2020

43. Kang S, Peng W, Zhu Y, Lu S, Zhou M, Lin W, et al. Recent progress in understanding 2019 novel coronavirus associated with human respiratory disease: detection, mechanism and treatment. Int J Antimicrob Agents 2020;55:105950.

44. Dou D, Revol R, Ostbye H, Wang H, Daniels R. Influenza a virus cell entry, replication, virion assembly and movement. Front Immunol 2018;9:1581.

45. Zhou F, Yu T, Du R, Fan G, Liu Y, Liu Z, et al. Clinical course and risk factors for mortality of adult inpatients with covid-19 in Wuhan, China: a retrospective cohort study. Lancet 2020;395:1054-62.

46. Poon LL, Peiris M. Emergence of a novel human coronavirus threatening human health. Nat Med 2020;26:317-9.

47. Peeri NC, Shrestha N, Rahman MS, Zaki R, Tan Z, Bibi S, et al. The SARS, MERS and novel coronavirus (COVID-19) epidemics, the newest and biggest global health threats: what lessons have we learned?. Int J Epidemiol 2020;49:717-26.

48. Zhang YZ, Holmes EC. A genomic perspective on the origin and emergence of SARS-CoV-2. Cell 2020;181:223-7.

49. Ralph R, Lew J, Zeng T, Francis M, Xue B, Roux M, et al. 2019$\mathrm{nCoV}$ (Wuhan virus), a novel Coronavirus: human-to-human transmission, travel-related cases, and vaccine readiness. Infect Dev Countrol 2020;14:3-17

50. Yang Y, Peng F, Wang R, Guan K, Jiang T, Xu G, et al. The deadly coronaviruses: The 2003 SARS pandemic and the 2020 nove coronavirus epidemic in China. J Autoimmun 2020;109:102434

51. Wu F, Zhao S, Yu B, Chen YM, Wang W, Song ZG, et al. A new coronavirus associated with human respiratory disease in China. Nature 2020;579:265-9.

52. Ye ZW, Yuan S, Yuen KS, Fung SY, Chan CP, Jin DY. Zoonotic origins of human coronaviruses. Int J Biol Sci 2020;16:1686.

53. Dilcher M, Werno A, Jennings LC. SARS-CoV-2: a novel deadly virus in a globalised world. N Z Med J 2020;133:6-11.

54. Chen H, Guo J, Wang C, Luo F, Yu X, Zhang W, et al. Clinical characteristics and intrauterine vertical transmission potential of COVID-19 infection in nine pregnant women: a retrospective review of medical records. Lancet 2020;395:809-15.

55. Huang C, Wang Y, Li X, Ren L, Zhao J, Hu Y, et al. Clinical features of patients infected with 2019 novel coronavirus in Wuhan, China. Lancet 2020;395:497-506.

56. Zhou P, Yang XL, Wang XG, Hu B, Zhang L, Zhang W, et al. A pneumonia outbreak associated with a new coronavirus of probable bat origin. Nature 2020;79:270-3.
57. Gormley M, Aspray TJ, Kelly DA. COVID-19: mitigating transmission via wastewater plumbing systems. Lancet Glob Health 2020;8:e643.

58. Wu JT, Leung $\mathrm{K}$, Bushman $\mathrm{M}$, Kishore N, Niehus R, de Salazar PM, et al. Estimating clinical severity of COVID-19 from the transmission dynamics in Wuhan, China. Nat Med 2020;26:506-10.

59. Hellewell J, Abbott S, Gimma A, Bosse NI, Jarvis CI, Russell TW, et al. Feasibility of controlling covid-19 outbreaks by isolation of cases and contacts. Lancet Glob Health 2020;8:e488-e496.

60. Prem K, Liu Y, Russell TW, Kucharski AJ, Eggo RM, Davies N, et al. The effect of control strategies to reduce social mixing on outcomes of the covid-19 epidemic in Wuhan, China: a modelling study. Lancet Public Health 2020;5:e261-e270.

61. World Health Organization. Severe acute respiratory infections treatment centre: practical manual to set up and manage a SARI treatment centre and a SARI screening facility in health care facilities. World Health Organization 2020. Available from: https://apps.who.int/iris/bitstream/handle/10665/331603/ WHO-2019-nCoV-SARI treatment_center-2020.1-eng.pdf. [Last accessed on 24 May 2020]

62. Wickramasinghe NC, Steele EJ, Gorczynski RM, Temple R, Tokoro G, Wallis DH, et al. Growing evidence against global infection-driven by person-to-person transfer of covid-19. Virol Curr Res 2020;4:110.

63. World Health Organization. Clinical management of severe acute respiratory infection (SARI) when COVID-19 disease is suspected: interim guidance, 13 March 2020. World Health Organization; 2020 Available from: https://apps.who.int/iris/bitstream/handle/10665/331446/ WHO-2019-nCoV-clinical-2020.4-eng.pdf. [Last accessed on 20 May 2020]

64. Bai Y, Yao L, Wei T, Tian F, Jin DY, Chen L, et al. Presumed asymptomatic carrier transmission of COVID-19. JAMA 2020;323:1406-7.

65. Cascella M, Rajnik M, Cuomo A, Dulebohn SC, Di Napoli R. Features, evaluation and treatment coronavirus (COVID-19). In: StatPearls. StatPearls Publishing; 2020.

66. $\mathrm{Xu} X \mathrm{XW}, \mathrm{Wu} \mathrm{XX}$, Jiang $\mathrm{XG}, \mathrm{Xu} \mathrm{KJ}$, Ying LJ, Ma CL, et al. Clinical findings in a group of patients infected with the 2019 nove coronavirus (SARS-Cov-2) outside of Wuhan, China: retrospective case series. Br Med J 2020;368:m606.

67. Centers for disease control and prevention. How COVID-19 spreads; 2020. Available from: https://www.cdc.gov/coronavirus/2019-ncov/preventgetting-sick/how-covid-spreads.html [Last accessed on 23 May 2020]

68. Guo YR, Cao QD, Hong ZS, Tan YY, Chen SD, Jin HJ, et al. The origin, transmission and clinical therapies on coronavirus disease 2019 (COVID-19) outbreak-an update on the status. Mil Med Res 2020;7:1-10.

69. Driggin E, Madhavan MV, Bikdeli B, Chuich T, Laracy J, Bondi Zoccai G, et al. Cardiovascular considerations for patients, health care workers, and health systems during the coronavirus disease 2019 (Covid-19) pandemic. J Am Coll Cardiol 2020;S0735-1097:34637-44.

70. Centers for disease control and prevention. Symptoms of coronavirus; 2020 Availabe from: https://www.cdc.gov/coronavirus/2019-ncov/symptomstesting/symptoms.html [Last accessed on 24 May 2020]

71. World Health organization (WHO). Coronavirus; 2020. Available from: https://www.who.int/healthtopics/coronavirus\#tab=tab_3 [Last accessed on 23 May 2020]

72. Wang $\mathrm{D}, \mathrm{Hu} \mathrm{B}, \mathrm{Hu} \mathrm{C}, \mathrm{Zhu} \mathrm{F}$ Liu $\mathrm{X}$, Zhang I, et al. Clinical characteristics of 138 hospitalized patients with 2019 novel coronavirus-infected pneumonia in Wuhan, China. JAMA 2020;323:1061-9.

73. Wang Y, Wang Y, Chen Y, Qin Q. Unique epidemiological and clinical features of the emerging 2019 novel coronavirus pneumonia (COVID-19) implicate special control measures. Med Virol 2020;92:568-76.

74. Chen N, Zhou M, Dong X, Qu J, Gong F, Han Y, et al. Epidemiological and clinical characteristics of 99 cases of 2019 
novel coronavirus pneumonia in Wuhan, China: a descriptive study. Lancet 2020;395:507-13.

75. Jiang F, Deng L, Zhang L, Cai Y, Cheung CW, Xia Z. Review of the clinical characteristics of coronavirus disease 2019 (COVID19). J Gen Intern Med 2020;35:1545-9.

76. Wu Z, McGoogan JM. Characteristics of and important lessons from the coronavirus disease 2019 (COVID-19) outbreak in China: summary of a report of 72314 cases from the Chinese Center for Disease Control and Prevention. JAMA 2020;323:1239-42.

77. Dong $\mathrm{L}, \mathrm{Hu} \mathrm{S}$, Gao J. Discovering drugs to treat coronavirus disease 2019 (COVID-19). Drug Discov Ther 2020;14:58-60.

78. National Health Commission. Notice regarding the issuance of a new coronavirus pneumonia diagnosis and treatment plan; 2020. Available from: http://www.nhc.gov.cn/yzygj/s7653p/202002/8334a8326dd 94d329df351d7da8aefc2/files/b218cfeb1bc54639af227f9 22bf6b817.pdf [Last accessed on 24 May 2020]

79. Wang Y, Zhu LQ. Pharmaceutical care recommendations for antiviral treatments in children with coronavirus disease 2019. World J Pediatr 2020;16:1-4

80. Ministry of Health and Family Welfare Directorate General of Health Services. Advisory for Human Resource Management of COVID-19; 2020. Available from: https://www.mohfw.gov.in/pdf/AdvisoryforHRmanagement.p df. [Last accessed on 23 May 2020]

81. Savarino A, Di Trani L, Donatelli I, Cauda R, Cassone A. New insights into the antiviral effects of chloroquine. Lancet Infect Dis 2006;6:67-9.

82. Yan Y, Zou Z, Sun Y, Li X, Xu KF, Wei Y, et al. Anti-malaria drug chloroquine is highly effective in treating avian influenza A H5N1 virus infection in an animal model. Cell Res 2013;23:300-

83. Colson P, Rolain J, Raoult D. Chloroquine for the 2019 novel coronavirus SARS-CoV-2. Int J Antimicrob Agents 2020;55:105923.

84. Hafid AF. The combination therapy model of andrographis paniculata extract and chloroquine on plasmodium berghei infected mice. Asian J Pharm Clin Res 2015;8:205-8.

85. Walmsley S, Bernstein B, King M, Arribas J, Beall G, Ruane P, et al. Lopinavir-ritonavir versus nelfinavir for the initial treatment of HIV infection. N Engl J Med 2002;346: 2039-46.

86. Pulido F, Arribas JR, Delgado R, Cabrero E, Gonzalez Garcia J, Perez Elias MJ, et al. Lopinavir-ritonavir monotherapy versus lopinavir-ritonavir and two nucleosides for maintenance therapy of HIV. AIDS 2008;22:F1-9.
87. Lin S, Shen R, Guo X. Molecular modeling evaluation of the binding abilities of ritonavir and lopinavir to wuhan pneumonia coronavirus proteases. bioRxiv 2020 https://doi.org/10.1101/2020.01.31.929695

88. Chu CM, Cheng VC, Hung IF, Wong MM, Chan KH, Chan KS, et al. Role of lopinavir/ritonavir in the treatment of SARS: initial virological and clinical findings. Thorax 2004;59:252-6.

89. Sheahan TP, Sims AC, Leist SR, Schafer A, Won J, Brown AJ, et al. Comparative therapeutic efficacy of remdesivir and combination lopinavir, ritonavir, and interferon beta against MERS-CoV. Nat Commun 2020;11:222.

90. Zumla A, Chan JF, Azhar EI, Hui DS, Yuen KY. Coronavirusesdrug discovery and therapeutic options. Nat Rev Drug Discovery 2016;15:327.

91. de Wit E, Feldmann F, Cronin J, Jordan R, Okumura A, Thomas $\mathrm{T}$, et al. Prophylactic and therapeutic remdesivir (GS-5734) treatment in the rhesus macaque model of MERS-CoV infection. P Natl Acad Sci 2020;117:6771-6.

92. Agostini ML, Andres EL, Sims AC, Graham RL, Sheahan TP, Lu X, et al. Coronavirus susceptibility to the antiviral remdesivir (GS5734 ) is mediated by the viral polymerase and the proofreading exoribonuclease. MBio 2018;9:e00221-18.

93. Kapoor KM, Kapoor A Role of chloroquine and hydroxychloroquine in the treatment of COVID-19 infection-A systematic literature review. medRxiv 2020. DOI:10.1101/2020.03.24.20042366

94. A PK, G P, Sn M, Ap S, Swamy V, Rama S. Clinical outcomes of use of hydroxychloroquine in paradoxical tuberculosis-immune reconstitution inflammatory syndrome in hiv-infected patients. Asian J Pharm Clin Res 2018;11:439-41.

95. Liu J, Cao $\mathrm{R}$, $\mathrm{Xu} \mathrm{M}$, Wang $\mathrm{X}$, Zhang $\mathrm{H}$, $\mathrm{Hu} \mathrm{H}$, et al. Hydroxychloroquine, a less toxic derivative of chloroquine, is effective in inhibiting SARS-CoV-2 infection in vitro. Cell Discovery 2020;6:16.

96. Xu X, Han M, Li T, Sun W, Wang D, Fu B, et al. Effective treatment of severe Covid-19 patients with Tocilizumab. ChinaXiv preprint; 2020. Available from: https://www.ser.es/wp-content/uploads/2020/03/TCZ-andCOVID-19.pdf [Last accessed on 24 May 2020]

97. UPHARMA Consulting healthcare. Available from: https://www.upharma-c.com/en/ [Last accessed on 24 May 2020]

98. Zhang S, Diao MY, Duan L, Lin Z, Chen D. The novel coronavirus (SARS-CoV-2) infections in China: prevention, control and challenges. Intensive Care Med 2020;46:591-3.

99. Jordan V. Coronavirus (Covid-19): infection control and prevention measures. J Prim Health Care 2020;12:96-7. 